AL IBTIDA: JURNAL PENDIDIKAN GURU MI (2020) Vol 7 (1) : 33-45

DOI: http://dx.doi.org/ 10.24235/al.ibtida.snj.v7i1.6020

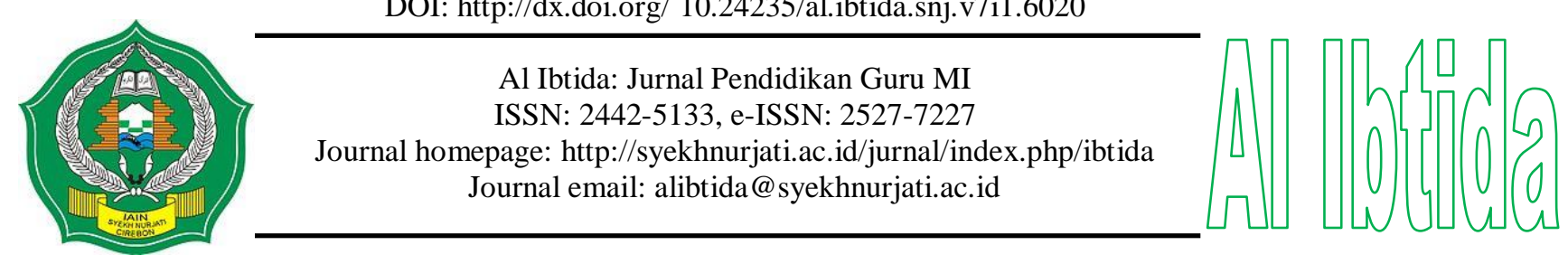

\title{
The Analysis of Students' Learning Obstacles on the Fraction Addition Material for Five Graders of Elementary Schools
}

\author{
Irfan Fauzi* \\ *Elementary Education Study Program, School of Postgraduate, \\ Universitas Pendidikan Indonesia, Bandung, Indonesia \\ Email: If96@upi.edu \\ Didi Suryadi** \\ **Department of Mathematics Education, Faculty of Mathematics and Natural Science, \\ Universitas Pendidikan Indonesia, Bandung, Indonesia \\ Email: ddsuryadi1@gmail.com
}

Received: February $11^{\text {th }}, 2020$. Accepted: March $26^{\text {th }}, 2020$. Published: June $07^{\text {th }}, 2020$.

\begin{abstract}
Various researchs have explained the students' difficulties in understanding fractions, so the researcher will analyze the student obstacle learning on fraction addition material. The approach used in this research is qualitative with the case study method. The subjects in this study were $5^{\text {th }}$ grade students of Geger Kalong Girang 1-2 elementary school, Bandung City with a total of 29 students. Collecting data in this study using tests, interviews, and documentation. Data analysis uses data reduction, data display, and conclusion drawing/verification. The results of this study found that students experience 1) ontogenic obstacle caused by the students inablity to understand the picture presented so that they are not able to determine the amount of fractions; 2) epistemological obstacle caused by the inability of students to understand fractions as part of the whole and apply the wrong concept in operating fractions; and 3) didactical obstacle caused by informal teaching methods and presentation of teaching materials that did not pay attention to student involvement. This research can facilitates students in understanding fraction addition material and provides an overview to the teacher in making teaching materials and learning design about fraction addition based on learning obstacle.
\end{abstract}

Keywords: learning obstacles, fraction addition, elementary school.

\begin{abstract}
Abstrak
Berbagai penelitian telah menjelaskan terkait dengan kesulitan siswa dalam memahami pecahan, sehingga peneliti akan menganalisis learning obstacle siswa pada materi penjumlahan pecahan. Pendekatan yang digunakan dalam penelitian ini adalah kualitatif dengan metode studi kasus. Subjek dalam penelitian ini adalah siswa kelas 5 SD Geger Kalong Girang 1-2 Kota Bandung dengan total 29 siswa. Pengumpulan data dilakukan dengan menggunakan tes, wawancara, dan dokumentasi. Adapun analisis data menggunakan reduksi data, penyajian data, dan penarikan kesimpulan. Hasil penelitian ini menunjukkan bahwa siswa mengalami 1) ontogenic obstacle disebabkan karena ketidakmampuan siswa dalam memahami
\end{abstract}


gambar yang disajikan, sehingga tidak mampu menentukan besaran pecahan pada gambar; 2) epistemological obstacle disebabkan karena ketidakmampuan siswa dalam memahami pecahan sebagai bagian dari keseluruhan dan menerapkan konsep yang salah dalam mengoperasikan pecahan; dan 3) didactical obstacle disebabkan karena cara mengajar guru yang bersifat informal dan penyajian bahan ajar yang kurang memperhatikan keterlibatan siswa. Penelitian ini dapat memfasilitasi siswa dalam memahami materi penjumlahan pecahan dan memberikan gambaran kepada guru dalam membuat bahan ajar dan desain pembelajaran penjumlahan pecahan berdasarkan learning obstacle.

Kata kunci: learning obstacle, penjumlahan pecahan, sekolah dasar.

\section{INTRODUCTION}

Mathematics became a very important subject taught in the 21 st century (Gravemeijer et al., 2017), it is needed to the children in receiving the knowledge and skills for theireveryday life (Deringol, 2018). According to Baykul (2009) mathematics is an important tool learned by students, and it can be used to solve problems in science. Mathematics will help students think creatively and critically to understand the world. But mathematics is still considered as a very difficult subject to understand (Markovits \& Forgasz, 2017), because it is a deductive and abstract science that uses the language of symbols, and it is difficult to understand by students who are still at the stage of concrete operational development (Widodo \& Kartikasari, 2017), then it is also supported by schools learning that are only required procedural problem solving, rather than fostering a complete understanding of mathematical concepts (Suci et al., 2014).

In understanding mathematical concepts comprehensively, there are several standards that teachers must pay attention in regarding the learning material, one of them is arithmetic learning. Numbers is the materials in arithmetic learning. It is very important material in elementary school. According to Verschaffel et al (2006) explain there are several reasons why numbers are so important for students to learn, among them are number operations and applications are closely related to students real life and they are often used it.Numbers is the basis of various materials in mathematics, and it is one of the first materials taught at school and students' dispositions for mathematics often depend on this number material.

From the explanation above, the teacher's role in teaching numbers is very important, the teacher have to teach the concept of numbers correctly, and ensure that students can learn numbers well as a basis for learning further material. There are various types of numbers to learn in elementary school, one of which is rational numbers. Rational numbers were first studied in elementary school in the form of fractions. The topic of fractions has begun to studied in low grades, even in some countries, the concept of fractions has been taught in 
grade 1 elementary schools (Alajmi, 2012). In Indonesia, fraction material is taught in grade 2 , and it continues until grade 6.

Fraction material is one of the most important aspects in the elementary school curriculum, because it encourages the students' mathematical abilities (Tonra, 2016). However, many students feel difficult to understand fractions (Rasyid et al., 2018; Irfan, 2017; Wahyuni, 2017). According to Hoch et al (2018) in his research explained that there were 33 international studies that examined fractions and found 58 typical errors empirically. This error is often systematic and shows a lack of conceptual understanding. For example, one systematic mistake made by students is adding two fractions to calculate the result by adding separately the numerator and denominator of a fraction without equating the denominator first, like $\frac{12}{13}+\frac{7}{8}$ and the way that is often found is students add 12 and 7 , and 13 and 8 so that it produces an answer $\frac{9}{21}$ (Clarke \& Roche, 2009).

Difficulties faced by students in the learning process should be analyzed by the teacher as part of his professional assignment, according to Sukirno \& Ramadhani (2014) when students find obstacles in their learning experience, it can be caused by the interaction system, the learning process that occurs, the nature of teaching from the teacher, the nature of the subject matter, genetic factors and personal development. Learning obstacles according to Brosseaou (2002) are divided into 3 parts, including 1) onto genic Obstacle is a learning barrier that occurs because of student limitations in a self-development or related to the mental readiness of student learning. According to Suryadi (2018a) explain that, if the teacher presents a very difficult material context, it will have an impact on students, they will experience obstacles to the learning process. Conversely, if it is too easy the students' development will be hampered and it will not increase their intellectual capacity; 2) epistemological Obstacle is an obstacle that occurs because of the limited knowledge possessed by students in certain contexts. Historical approach analysis is needed to find out the epistemological obstacle. Historical approach looks at how (a) explain the knowledge and understand its use; (b) explain the advantages of using previous understanding; (c) see the relationship among the concepts; (d) identify the problems and providing reasons for resolution; and (e) repeat responses to the same or similar problems, and how they understand the reason; and 3) didactical Obstacle arises from the method or approach used by the teacher. According to Suryadi (2018b) that the sequence and stages of the curriculum including its presentation in class can result the didactical obstacle. The order of material structurally (representing the concepts interrelationship) and functional sequences (representing the continuity of thought processes) have an effect on one's learning process. Likewise, the stages 
of presenting the material (less detailed or too detailed) will have a significant effect on learning. Didactical obstacle is caused by sequencing factors and / or stages of presentation in the curriculum that have an impact on the inhibition of the continuity of students' thinking processes.

Learning obstacle that arises is very closely related to the learning process, so the teacher, students, and the material are important to be analyzed in detail. It is because of all three are the basic elements in learning depicted in a didactic triangle which includes students, teachers and teaching materials.

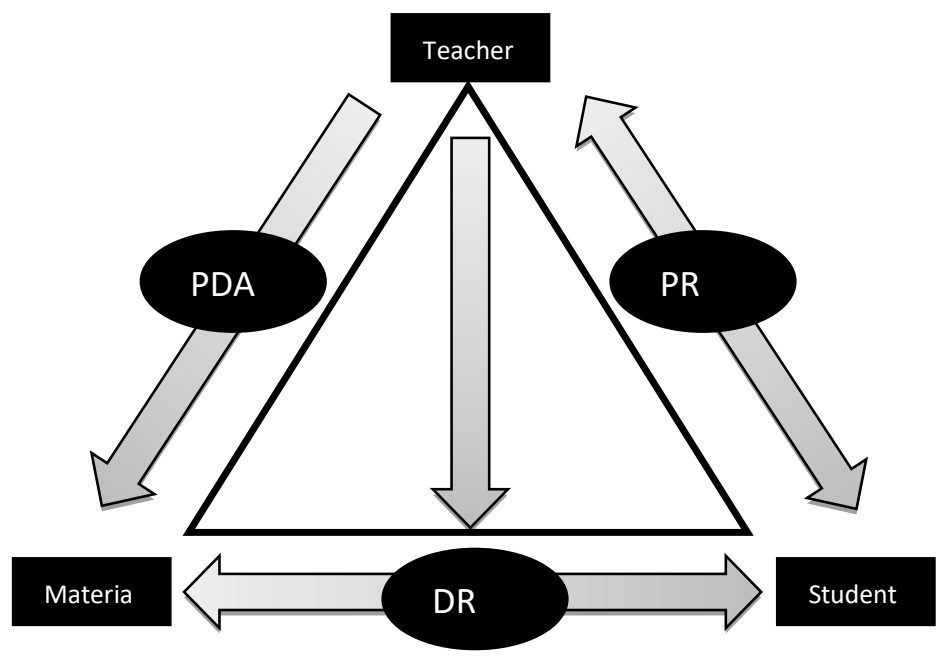

Information:

Figure 1. Three basic elements of learning

DR : Didactic Relations

PR : Pedagogical Relations

PDA : Pedagogical Didactic Anticipation

The teacher has an important role to facilitate students in building their knowledge and experience that guides them to achieve the expected learning goals. Teacher's role in teaching mathematics is very important (Ho \& Hedberg, 2005), the teacher should be able to serve meaningful learning and presenting the correct concepts, because it will affect the contexts obtained by students. In addition, teaching materials become an important aspect and an inseparable part of the learning process, teaching materials can help teachers/instructors in conducting learning activities (Majid, 2013).

Many studies describe fractions in elementary schools, both in terms of difficulties (Gabriel et al., 2013; Nuraini et al., Hansen et al., 2017; 2016; Wijaya, 2017) and in terms of their comprehension ability (Nicolaou \& Pitta-Pantazi, 2016), but the study only analyzed student difficulties based on the aspects of student knowledge without explaining the various other aspects behind them Learning obstacle analysis in this study will describe in detail about student difficulties both in terms of the level and understanding of their knowledge and from 
the presentation of material in textbooks and the way teachers teach. It needs to be done because the learning process involves the most important elements, namely students, material and teachers, so this research can facilitate students to understand fraction addition well without experiencing the learning obstacle found in this study, besides this research can be used in designing material and teacher's reference in planning, implementing and evaluating mathematics learning, especially in fraction addition material in grade 5 elementary schools based on learning obstacle.

\section{METHODS}

This research uses a qualitative approach. According to Prabowo \& Heriyanto (2013) qualitative research is research that has a relationship with the ideas or views of the subjects studied. Meanwhile, according to Lestari \& Yudhanegara (2015) that qualitative research is methods to explore and understand the meaning by a number of individuals or groups of people ascribed to social or humanitarian problems. This research uses a case study method, according to Gall et al (1999) that case studies are carried out to explain certain phenomena, such as individuals, programs, processes, and so on. So the case study is considered as the right method to reveal in detail about students' obstacle learning on fraction addition material in grade 5 elementary school.

The subjects in this study were $5^{\text {th }}$ grade students of Geger Kalong Girang 1-2 elementary school, Bandung City with a total of 29 students. Data collection techniques are: 1) test, written tests to see the learning obstacles that appear related to fraction addition material in grade 5 elementary school student; 2) interview, in this study, interviews were given to uncover the students mindset of in giving the answers as stated in the questions were given, interviews were also given to the teacher in seeing the concept of shadows and how teacher teach fraction addition material in grade 5 elementary schools; and 3) documentation, the documentation used in this study was analyzing grade 5 textbooks used in the learning process.

Data analysis conducted in this study was carried out in three stages, 1) data reduction, the researcher records all student responses in answering questions related to the fraction addition; 2) data display, the researcher began to classify the types of student responses and identify based on their difficulties and 3) drawing/verification, the researcher analyzed in detail the types of student learning difficulties in the fraction addition material in grade 5 elementary schools based on the obstacle learning theory. 


\section{RESULTS AND DISCUSSION}

Obstacle learning test given to students in grade 5 at Geger Kalong Girang 1-2 elementary school, Bandung City, which amounted to 28 students, the test given is then identified to see the students 'obstacles, from various responses that appear on students' answers, the researcher notes that there are some obstacles that occur among students, including 1) the inability of students to understand the images presented, resulting in students' difficulty in determining fractions; 2) the inability of students to understand fractions as part of the whole; and 3) the inability of students to operate fractions. The above obstacles are then analyzed based on the learning obstacle theory, namely ontogenic obstacle, epistemological obstacle, and didactical obstacle. The results of the analysis of students' learning obstacles in the fraction addition material are as follows.

\section{Ontogenic Obstacles}

Ontogenic obstacle is based on the limitations of the student's self-related to the mental readiness of student. The obstacle that appears on the fraction summing problem related to ontogenic is the difficulty of students in understanding the purpose of the picture presented in the problem.

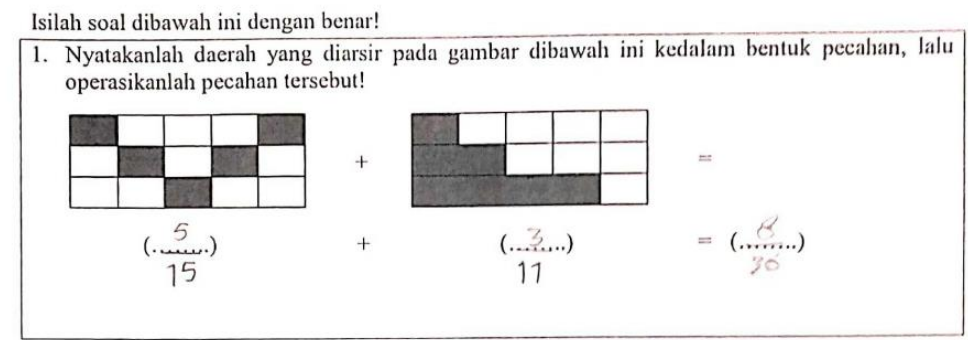

Figure 2. Ontogenic Obstacle

Students already understand the concept of fractions as part of the whole in a simple way, but in the picture above two shaded images are presented, the first picture has five shaded parts with the same size, and the second picture is three shaded parts in different of size. Students understand the first picture and write the answer correctly, but in the second, students feel confused and only focus on the shaded image, even though the picture has a different size, students should be able to solve it by making line down, so the parts are the same, and it can be expressed in the form of fractions as part of a whole that has the same size.

Usually students get a problem in fractions of the same size picture, so they can immediately determine the fraction, but in the picture above they present problems that they did not normally find before, so it causes students felt difficult to answer the question. Students focus on the shaded image without regard to its size. It can be said that the obstacle 
above is ontogenic because of the inability of students to determine the fraction value of an image; this is because students do not understand the shape of the image presented.

According to Malikha \& Amir (2018) related to the meaning of fractions which means that part of the whole is interpreted differently by students, is students do not pay attention to the part of the whole. Suryadi (2018b) explained that students who are always given easy material will be hampered by the development of their thinking. Learning should be built based on constructivist or in Vygotsky's view that learning must start from the top-down rather than bottom-up which means students start with complex problems for them to solve, then discover (with the guidance of the teacher) the basic skills needed (Jatisunda, 2017).

\section{Epistemological Obstacle}

Epistemological obstacle is related to the limited knowledge possessed by students in certain contexts. Epistemological obstacle that appears to students in relation to fraction addition is students do not understand the concept of fractions which means they are part of the whole.

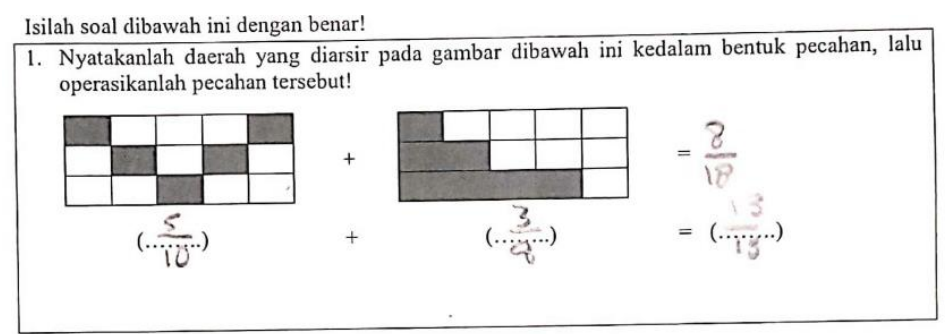

Figure 3. Epistemological Obstacle 1

Based on the results of the interview, students understand the concept of fractions is comparing the shaded parts with those that are not shaded, so that from the picture above the results of the fraction are obtained $\frac{5}{10}$ and $\frac{3}{8}$, according to Nguyen et al (2017) that students still do not understand the nature of fractions and the equality of parts, it is because students consider the denominator and numerator in fractions as two separate integers (Şiap \& Duru, 2004).

The second epistemological Obstacle related to fraction addition lies in the way students operate fractions

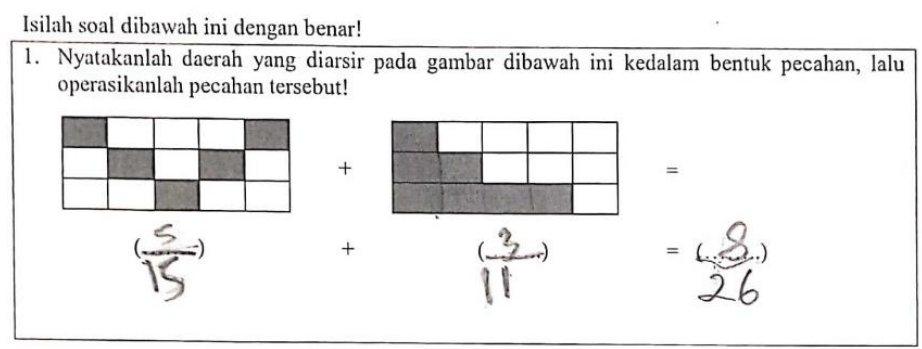

Figure 4. Epistemological Obstacle 2 
Although the questions presented above should produce fraction answers with the same whole section, but based on the results of the interviews show that in solving fraction questions, students immediately add up the denominator with the denominator and numerator with the numerator, the way students do: $\frac{5}{15}+\frac{3}{11}=\frac{5+3}{15+11}=\frac{8}{26}$. Students do not understand that operating the sum of different denominator fractions must be equated first the denominator, then operate by adding only the numerator and the denominator part is the same number, it also applies to the sum of fractions with the same denominator.

According to Aksoy \& Yazlik (2017) this difficulty is because students do not use modeling in fraction operations, while Hoch et al (2018) explain that students apply the wrong system and show a lack of conceptual understanding.

\section{Didactical Obstacle}

Didactical Obstacles can be caused by the use of teacher strategies and methods in teaching, in addition to the presentation of the material in textbooks also becomes the basis for the emergence of obstacles owned by students. Didactical obstacle that appears is related to the addition of fractions, students complete the addition of fractions by the wrong procedure.

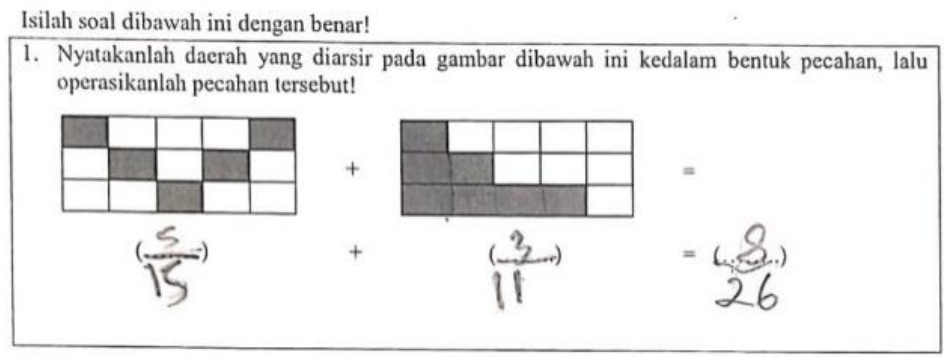

Figure 5. Didactical Obstacle

Based on the results foundthat teachers only deliver the material directly based on textbooks without involving students and the environment.The source of information on learning is only from the teacher. Besides the teacher only presents the context of routine questions to students, this is also explained by students that the context of the questions they have never found before, and has never been taught by the teacher.

Based on the analysis of the textbook used, it was found that the presentation of questions given was more symbolic, students were immediately presented formally and not even involving real context in their daily lives. 


\begin{tabular}{|c|c|c|}
\hline \multicolumn{3}{|c|}{ Ayo Berlatih 11.5 } \\
\hline \multicolumn{3}{|c|}{ Kerjakan soal-soal berikut! } \\
\hline 1. $\frac{4}{15}+\frac{11}{15}=\ldots$ & 6. $\frac{3}{8}+\frac{3}{10}=\ldots$ & 11. $\frac{1}{2}+\frac{2}{3}+\frac{1}{12}=\ldots$ \\
\hline 2. $\frac{2}{4}+\frac{1}{4}=\ldots$ & 7. $\frac{5}{12}+\frac{7}{18}=\ldots$ & 12. $\frac{3}{2}+\frac{7}{9}+\frac{2}{6}=\ldots$ \\
\hline 3. $\frac{1}{12}+\frac{9}{12}=\ldots$ & 8. $\frac{2}{3}+\frac{5}{6}=\ldots$ & 13. $\frac{4}{9}+\frac{2}{15}+\frac{1}{3}=\ldots$ \\
\hline 4. $\frac{5}{12}+\frac{1}{2}=\ldots$ & 9. $\frac{5}{6}+\frac{7}{8}=\ldots$ & 14. $\frac{1}{4}+\frac{2}{5}+\frac{3}{6}=\ldots$ \\
\hline 5. $\frac{1}{3}+\frac{6}{8}=\ldots$ & 10. $\frac{3}{4}+\frac{4}{5}=\ldots$ & 15. $\frac{5}{6}+\frac{3}{5}+\frac{1}{10}=\ldots$ \\
\hline
\end{tabular}

Figure 6. Forms of questions in textbooks

In textbooks, there is no mental action that can build students' knowledge in understanding the fraction addition material, It can be seen in the picture below.

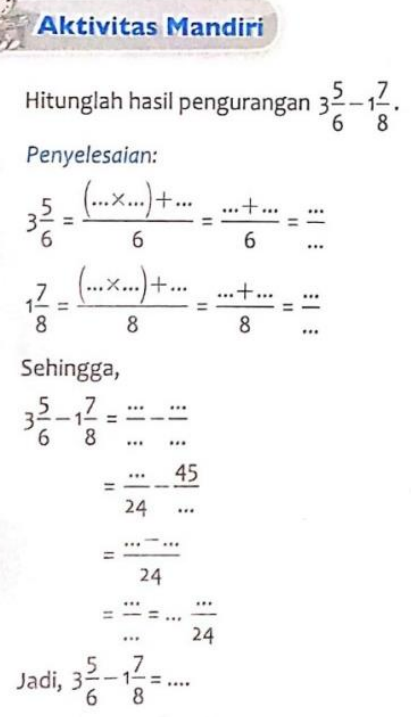

Figure 7. Student activities in textbooks

In the learning process, the presentation of the context of problem given to students is only an example of the problem, and student activity in solving the problem is directed to the example that has been given previously, so it can be said that in the learning process does not form equilibration in students, whereas according to Piaget (Ibda, 2015) that equilibration is a process of students to achieve higher levels of cognitive function through gradual assimilation and accommodation. Equilibration is created when a child tries to understand a new thing. It cannot be handled with existing schemes and knowledge so that disequilibrium is formed, but after that a process of restoring a balance called equilibrium will emerge, in this process students experience a meaningful learning process.

The activity of giving examples and questions with the aim of students to imiatate does not form an active learning environment, whereas to create a meaningful learning process, Brosseaou (2002) emphasizes that students can interact with various parties. The learning process in the textbook is only one-way, and there is no reciprocal process. 


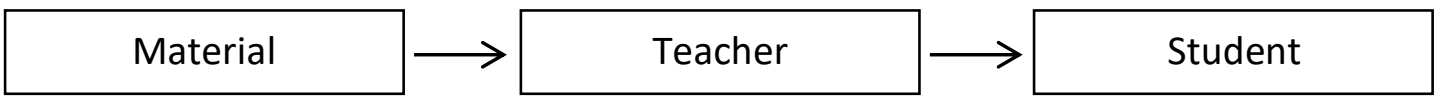

Figure 8. The process of forming knowledge seen in textbooks

From the picture above, the teacher only teaches examples of material from books to students, as a result students only imitate what the teacher taught, without being actively involved in finding existing formulas/understandings (Johar, 2013), so that the memories formed are only temporary (short time memory). Accordingto Turmudi (2008) the degree of attachment can also be said to be low, this is the reason for the emergence of obstacles in students.

The learning process should involve assimilation, accommodation, and schemes. Assimilation is an aspect of organism activity in which environmental elements are integrated into the organizational structure of a pre-existing organism (i.e. the relationship between elements), then in this case the knowledge that is already owned by students will greatly determine a good learning process (Gazali, 2016), at the time of assimilation, a person uses existing structures or abilities to deal with the problems he faces in his environment (Dahar, 2011). Whereas accommodation is an aspect of activity in which the existing organism schemes are differentiated and modified in response to the environment. According to Piaget that cognitive structure as a scheme is a way of perceiving, understanding and thinking about the world (Hill et al., 2008). The formation and change of this becomes the essence of cognitive development. Then, teachers must apply meaningful learning, learning can be done when students can use the knowledge they learn to solve problems and to understand new concepts by transferring their knowledge to the new situations and problems (Haylock \& Thangata, 2007)

\section{CONCLUSION}

Based on the results of the data obtained, it can be concluded that some students experience learning obstacles on the fraction addition material, while the learning obstacles are as follows: 1) ontogenic obstacle, namely the inability of students to determine the fractional value of an image, 2) epistemological obstacle that students do not understand the meaning of fractions is part of the whole and implements the wrong system in solving fraction addition, and 3) didactical obstacle that is the teacher only teaches fraction addition material informally besides the presentation of material in the textbook does not pay much attention to the involvement of students to build their knowledge independently. This research is expected to contribute to Indonesian education, especially in the field of elementary school mathematics learning. The findings of this study are also expected to facilitate teachers in 
developing teaching materials and make learning designs that are in accordance with the real conditions of students.

\section{REFERENCES}

Aksoy, N. C., \& Yazlik, D. O. (2017). Student Errors in Fractions and Possible Causes of These Errors. Journal of Education and Training Studies, 5(11), 219. https://doi.org/10.11114/jets.v5i11.2679.

Alajmi, A. H. (2012). How Do Elementary Textbooks Address Fractions? A Review of Mathematics Textbooks in The USA, Japan, and Kuwait. Educational Studies in Mathematics, 79(2), 239-261. https://www.jstor.org/stable/41413109.

Baykul, Y. (2009). İlköğretim Matematik Öğretimi. Ankara: Pegem A Yayınc1lık.

Brosseaou, G. (2002). Theory of Didactical Situation in Mathematics. New York, Boston, Dordrecht, London, Moscow: Kluwer Academic Publishers.

Clarke, D. M., \& Roche, A. (2009). Students' fraction Comparison Strategies as a Window into Robust Understanding and Possible Pointers for Instruction. Educational Studies in Mathematics, 72(1), 127-138. https://doi.org/10.1007/s10649-009-9198-9.

Dahar, R. . (2011). Teori Belajar dan Pembelajaran. Jakarta: Erlangga.

Deringol, Y. (2018). Primary School Students' Mathematics Motivation and Anxieties. Cypriot Journal of Educational Sciences, 13(4), 537-548. https://doi.org/10.18844/cjes.v13i4.3462.

Gabriel, F., Coché, F., Szücs, D., Carette, V., Rey, B. ., \& Content, A. (2013). A Componential View of Children's Difficulties in Learning Fractions. Developmental Psychology, 715(4), 1-12.

Gall, M. D., Gall, J. P., \& Borg, W. R. (1999). Applying Educational Research: How to Read, Do, and Use Research (6th ed.). New York: Pearson.

Gazali, R. . (2016). Pengembangan Bahan Ajar Matematika untuk Siswa SMP Berdasarkan Teori Belajar Ausubel. PYTHAGORAS: Jurnal Pendidikan Matematika, 11(2), 182192.

Gravemeijer, K., Stephan, M., Julie, C., Lin, F. L., \& Ohtani, M. (2017). What Mathematics Education May Prepare Students for the Society of the Future? International Journal of Science and Mathematics Education, 15, 105-123. https://doi.org/10.1007/s10763017-9814-6.

Hansen, N., Jordan, N. C., \& Rodrigues, J. (2017). Identifying Learning Difficulties with Fractions: A Longitudinal Study of Student Growth from Third through Sixth Grade. Contemporary Educational Psychology, 50, 45-59. https://doi.org/10.1016/j.cedpsych.2015.11.002.

Haylock, D., \& Thangata, F. (2007). Key Concepts in Teaching Primary Mathematics. London, UK: SAGE Publications Ltd.

Hill, H. C., Blunk, M. L., Charalambous, C. Y., Lewis, J. M., Phelps, G. C., Sleep, L., \& Ball, D. L. (2008). Mathematical Knowledge for Teaching and The Mathematical Quality of Instruction: An Exploratory Study. Cognition and Instruction, 26(4), 430-511. https://doi.org/10.1080/07370000802177235.

Ho, K. F., \& Hedberg, J. G. (2005). Teachers' Pedagogies and Their Impact on Students' Mathematical Problem Solving. Journal of Mathematical Behavior, 24(3), 238-252. 
Hoch, S., Reinhold, F., Werner, B., Richter-Gebert, J., \& Reiss, K. (2018). Design and Research Potential of Interactive Textbooks: The Case of Fractions. ZDM Mathematics Education, 50(5), 839-848. https://doi.org/10.1007/s11858-018-0971-z.

Ibda, F. (2015). Perkembangan Kognitif: Teori Jean Piaget. Jurnal Intelektualita, 3(1), 27-38.

Irfan, M. (2017). Bentuk a/b: sebagai Pecahan, Pembagian, atau Perbandingan? Jurnal Penelitian Pendidikan Dan Pengajaran Matematika, 3(1), 45-50.

Jatisunda, M. G. (2017). Pengaruh Pendekatan Konstruktivisme terhadap Pemecahan Masalah Matematik Peserta Didik. Jurnal Theorems(The Original of Mathematics), 2(1), 5766.

Johar, R. (2013). Pengembangan Model Pembelajaran Matematika Realistik Menuju Aceh Madani (Model Pm-Rahma). Jurnal Pendidikan Matematika, 3(1), 1-10. https://doi.org/10.22342/jpm.3.1.322.

Lestari, K. E., \& Mokhamad Ridwan Yudhanegara. (2015). Penelitian Pendidikan Matematika. Bandung: Refika Aditama.

Majid, A. (2013). Perencanaan Pembelajaran. Bandung: PT Remaja Rosdakarya.

Malikha, Z., \& Amir, M. F. (2018). Analisis Miskonsepsi Siswa Kelas V-B MIN Buduran Sidoarjo pada Materi Pecahan ditinjau dari Kemampuan Matematika. Pi: Mathematics Education Journal, 1(2), 75-81. https://doi.org/10.21067/pmej.v1i2.2329

Markovits, Z., \& Forgasz, H. (2017). "Mathematics is like a Lion": Elementary Students' Beliefs about Mathematics. Educational Studies in Mathematics, 96(1), 49-64. https://doi.org/10.1007/s10649-017-9759-2

Nguyen, P. L., Duong, H. T., \& Phan, T. C. (2017). Identifying The Concept Fraction of Primary School Students: The Investigation in Vietnam. Educational Research and Reviews, 12(8), 531-539. https://doi.org/10.5897/err2017.3220

Nicolaou, A., \& Pitta-Pantazi, D. (2016). Hierarchical Levels of Abilities that Constitute Fraction Understanding at Elementary School. International Journal of Science and Mathematics Education, 14(4), 757-776.

Nuraini, N. L. S., Suhartono, S., \& Yuniawantika, Y. (2016). Kesalahan Siswa pada Operasi Penjumlahan dan Pengurangan Pecahan di Kelas VI Sekolah Dasar. Sekolah Dasar: Kajian Teori Dan Praktik Pendidikan, 25(2), 168-175. https://doi.org/10.17977/um009v25i22016p168

Prabowo, A., \& Heriyanto. (2013). Analisis Pemanfaatan Buku Elektronik (E-Book) oleh Pemustaka di Perpustakaan SMA Negeri 1 Semarang. Jurnal Ilmu Perpustakaan, 2(2), 1-9. http://ejournal-s1.undip.ac.id/index.php/jip\%5CnANALISIS.

Rasyid, M. A., Budiarto, M. T., \& Lukito, A. (2018). Junior High School Students' Reflective Thinking on Fraction Problem Solving: In Case of Gender Differences. Journal of Physics: Conference Series, 947(1), 1-6. https://doi.org/10.1088/17426596/947/1/012041

Şiap, İ., \& Duru, A. (2004). The Ability to Use Geometrical Models in Fractions. Kastamonu Education Journal, 12(1), 89-96.

Suci, A., Martha, D., \& Basuki, F. H. (2014). Perancangan Game Edukatif (Perhitungan Matematika Sederhana ). Jurnal Komputer Bisnis, 456, 29-34.

Sukirno, \& Ramadhani, D. (2014). Analisis Learning Obstacles dalam Pembelajaran Pemecahan Masalah Penjumlahan Pecahan pada Siswa Kelas IV SD. Jurnal 
Pendidikan MIPA, 15(1), 77-83.

Suryadi, D. (2018a). Landasan Filosofis Penelitian Desain Didaktis (DDR). Bandung: Departemen Pendidikan Matematika UPI.

Suryadi, D. (2018b). Ontologi dan Epistemologi dalam Penelitian Desain Didaktis (DDR). Bandung: Departemen Pendidikan Matematika UPI.

Tonra, W. S. (2016). Pembelajaran Number Sense untuk Meningkatkan Hasil Belajar Siswa Sekolah Dasar pada Materi Pecahan. 5(2), 109-116.

Turmudi. (2008). Landasan Filsafat dan Teori Pembelajaran Matematika (Berparadigma Eksploratif dan Investigatif). Jakarta: Leuseur Cipta Pustaka.

Verschaffel, L., Greer, B., \& Torbeyns, J. (2006). Numerical thinking. In: Gutiérrez A, Boero $P$ (eds) Handbook of Research on The Psychology of Mathematics Education: Past, Present and Future. Rotterdam: Sense Publishers.

Wahyuni, R. S. (2017). Membandingkan Bilangan Pecahan Menggunakan Fraction Circle terhadap Pemahaman Konsep Siswa. Jurnal Gantang, 2(1), 21-26.

Widodo, S., \& Kartikasari, K. (2017). Pembelajaran Pemecahan Masalah Matematis Siswa Sekolah Dasar dengan Model Creative Problem Solving (Cps). Prisma, 6(1). https://doi.org/10.35194/jp.v6i1.28.

Wijaya, A. (2017). The Relationships between Indonesian Fourth Graders' Difficulties in Fractions and The Opportunity to Learn Fractions: A Snapshot of TIMSS Results. International Journal of Instruction, 10(4), 221-236. https://doi.org/https://doi.org/10.12973/iji.2017.10413a. 